Primljen / Received: 8.8.2016. Ispravljen / Corrected: 4.2.2017.

Prihvaćen / Accepted: 30.3.2017.

Dostupno online / Available online: 10.5.2017.

\section{Measurement of bridge dynamic displacements and natural frequencies by RTS}

Authors:

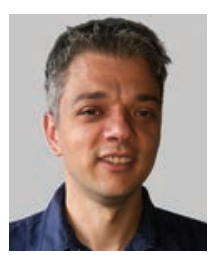

Assist.Prof. Ante Marendić, PhD. Geod.

University of Zagreb

Faculty of Geodesy

amarendic@geof.hr

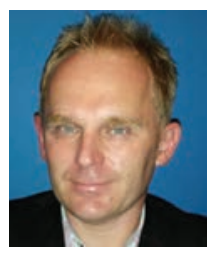

Assist.Prof. Rinaldo Paar, PhD. Geod.

University of Zagreb

Faculty of Geodesy

rpaar@geof.hr

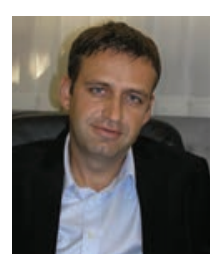

Assist.Prof. Domagoj Damjanović, PhD. CE University of Zagreb

Faculty of Civil Engineering

ddomagoj@grad.hr
Preliminary report

\section{Ante Marendić, Rinaldo Paar, Domagoj Damjanović}

\section{Measurement of bridge dynamic displacements and natural frequencies by RTS}

The use of RTS for measuring displacements at the Sava railway bridge during load testing after bridge rehabilitation is presented in the paper, and a special emphasis is placed on the determination of displacements when the bridge was subjected to dynamic load and natural frequencies. Measurement results are compared to numerical analysis results and to natural frequency results obtained by the Operational Modal Analysis (OMA).

\section{Key words:}

RTS, dynamic displacements, load testing, natural frequencies of the bridge, OMA

Prethodno priopćenje

Ante Marendić, Rinaldo Paar, Domagoj Damjanović

Određivanje dinamičkih pomaka i vlastitih frekevecija mosta RTS-om

U radu je prikazana primjena RTS-a za mjerenje pomaka na željezničkom mostu "Sava" tijekom pokusnog opterećenja nakon rekonstrukcije mosta, s posebnim naglaskom na određivanje pomaka pri dinamičkom djelovanju opterećenja te vlastitih frekvencija mosta. Rezultati mjerenja su uspoređeni s rezultatima numeričkog proračuna i s rezultatima vlastitih frekvencija određenih operacionalnom modalnom analizom (OMA).

Ključne riječi:

RTS, dinamički pomaci, pokusno opterećenje, vlastite frekvencije mosta, OMA

Vorherige Mitteilung

Ante Marendić, Rinaldo Paar, Domagoj Damjanović

\section{Ermittlung dynamischer Verschiebungen und Eigenfrequenzen von Brücken mittels RTS}

In dieser Arbeit wird die Anwendung des RTS zur Messung von Verschiebungen an der Eisenbahnbrücke "Sava" im Laufe von Versuchsbelastungen nach der Rekonstruktion der Brücke dargestellt, wobei das Hauptaugenmerk auf die Ermittlung von Verschiebungen bei dynamischen Lasteinwirkungen, bzw. Eigenfrequenzen gelegt wird. Die Messresultate werden Resultaten numerischer Berechnungen sowie durch operationale Modalanalyse (OMA) ermittelten Eigenfrequenzen gegenübergestellt.

Schlüsselwörter:

RTS, dynamische Verschiebungen, Versuchsbelastung, Eigenfrequenzen von Brücken, OMA 


\section{Introduction}

Bridges are of exceptional importance for traffic infrastructure of every country. Any kind of damage or significant deformation affects the safety of bridges and can result in their closure, which can then cause the collapse and disintegration of the traffic system [1]. Bridge inspections are necessary in order to ensure safe and functional operation of traffic. Continuous monitoring of displacements provides early warning in case of unforeseen damage.

Bridges are subjected to load testing in order to verify their design features and capabilities to take over design loads. According to Croatian legislation [2], every railway bridge with a span longer than $10 \mathrm{~m}$ has to be tested before it is opened to traffic. Generally, bridge load testing consists of static and dynamic tests. Accurate levels, total stations and Global Navigation Satellite Systems-GNSS instruments are most often used for static load testing depending on bridge characteristics and expected displacements [3, 4]. Older models of these instruments were not used for dynamic testing due to their limitations with regard to sampling frequency and accuracy. Sampling frequency of older RTS instruments amounts to $1 \mathrm{~Hz}$ [5], which is insufficient for measurement of dynamic displacements. With constant improvements of GNSS instruments and robotic total stations (RTS), these instruments are no longer limited to merely monitoring static displacements of the structures, i.e. they are now used for monitoring dynamic displacements as well. In recent years, GNSS instruments with the sampling frequency of 10-20 $\mathrm{Hz}$ have generally been used for monitoring displacements caused by dynamic excitation at large and flexible bridges [6-8]. A major requirement for GNSS measurements is the unobstructed view of the horizon and satellites. This is usually not the case during the load testing of railway bridges where satellite signals are deformed or even disrupted by the passing trains $[9,10]$. In such situations, an alternative is to use more recent RTS models that can accurately measure position of the moving point (reflector) with the sampling frequency of up to $20 \mathrm{~Hz}$ [11]. Another advantage of RTS is the possibility of recording $3 \mathrm{D}$ coordinates of a moving target with a millimetre level accuracy, compared to measurement quality obtained by GNSS instruments which is in centimetre level accuracy. Just like GNSS, RTS also has some limitations. Achievement of the level of accuracy by RTS is limited by a number of factors and requires direct visibility between the reflector mounted on the moving point and RTS, while the distance between RTS and the reflector should not exceed the optimal operational range of the RTS, which currently amounts to several hundreds of meters. To date, however, only a few research campaigns have been conducted where RTS instruments (with sampling frequency of 5-7 Hz) were used for measuring simulated and actual dynamic displacements of bridges [10, 12-15].

This paper presents RTS possibilities and its implementation in the dynamic testing of the Sava Railway Bridge during the load testing conducted following the bridge reconstruction. During the testing, the bridge was excited by two trains passing at speeds ranging from 20 to $75 \mathrm{~km} / \mathrm{h}$. Bridge displacements during dynamic excitation were measured by two RTS models with sampling frequencies of $10 \mathrm{~Hz}$ and $20 \mathrm{~Hz}$ at the measuring point situated at the quarter of the main span.

The paper focuses on the ability of RTS to measure bridge displacements during dynamic excitation, and on its efficiency in identifying bridge natural frequencies based on dynamic displacement measurements. Measured frequencies are compared to theoretical results obtained from the numerical model of the bridge. They are also compared with the results of the Operational Modal Analysis based on acceleration measurements.

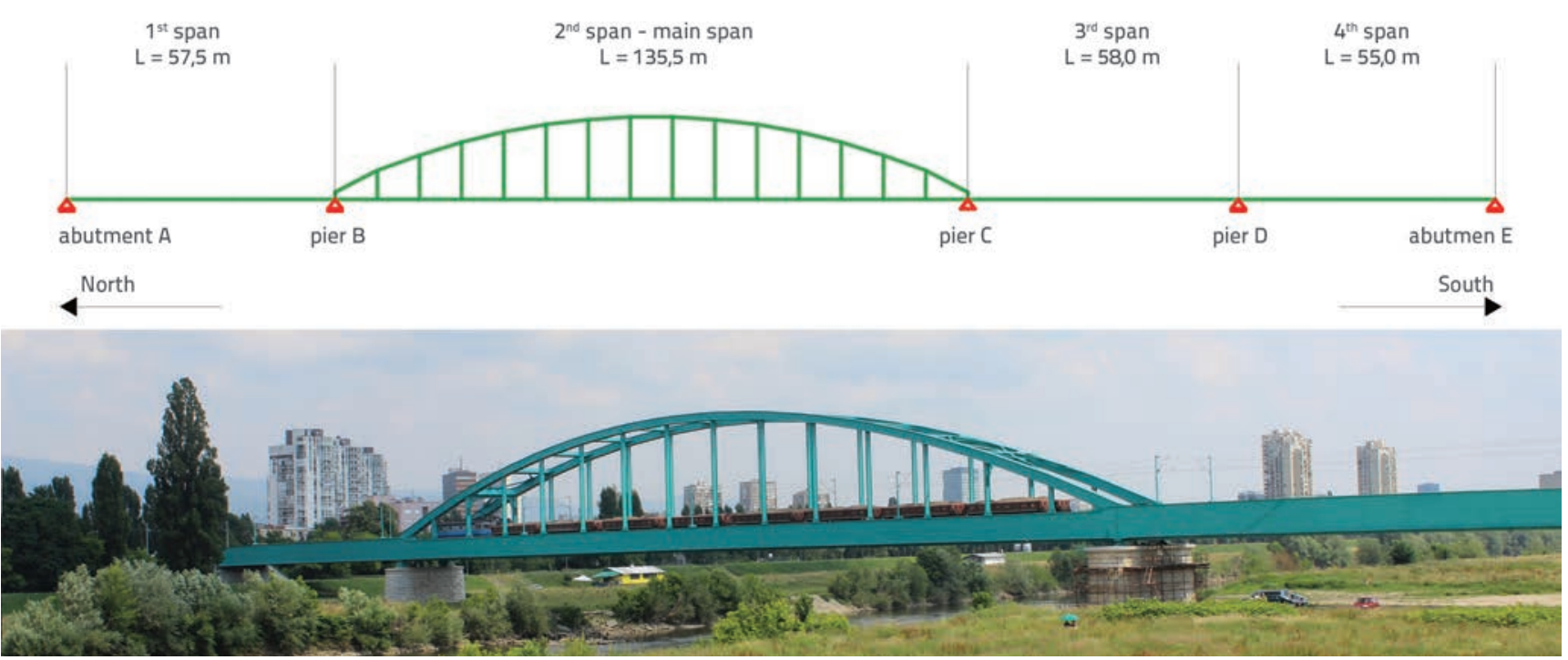

Figure 1. Sava Railway Bridge - longitudinal layout (above) and Bridge photo (below) 
Table 1. Train passages during dynamic load testing

\begin{tabular}{|c|l|l|c|}
\hline Event & Excitation type & Direction & Train speed [km/h] \\
\hline 1 & Simultaneous passage of 2 trains & From south to north & 20 \\
\hline 2 & Passage of 1 train at the west track & From north to south & 20 \\
\hline 3 & Simultaneous passage of 2 trains & From south to north & 40 \\
\hline 4 & Simultaneous passage of 2 trains & From south to north & 60 \\
\hline 5 & Simultaneous passage of 2 trains & From north to south & 20 \\
\hline 6 & Simultaneous passage of 2 trains * & From south to north & 75 \\
\hline \multirow{2}{*}{ * passage of two trains wasn't exactly simultaneous } & & \\
\hline
\end{tabular}

\section{Reconstruction of Sava Railway Bridge}

The Sava Railway Bridge is a double-track railway bridge over the Sava River in Zagreb. The bridge is a four-span steel structure measuring $306 \mathrm{~m}$ in total length and $9.6 \mathrm{~m}$ in width. The static system of the bridge is a simply supported continuous beam strengthened by the arch in the main span (Langer beam). The main span is $135.54 \mathrm{~m}$ long, and the remaining three spans mesure 57.50 m, $57.96 \mathrm{~m}$ and $55.00 \mathrm{~m}$ in length (Figure 1).

The bridge substructure is composed of two abutments and three piers. Piers and abutments are made of concrete with ashlar facing. Piers B, C, D and abutment E have caisson foundations, while abutment $A$ has massive concrete foundations. Roller bearings, movable in longitudinal direction of the bridge, are installed at abutments and piers B and D. Bearings at pier C are longitudinally fixed, the one at the upstream side is fixed in lateral direction, and the one at the downstream side is movable in lateral direction.

Main girders, arches and side hangers are made of steel grade S355, while steel grade S235 is used for all other elements. The bridge strengthening had to be performed in order to increase the bridge category to D4 (mass per axle of $22.5 \mathrm{t}$, and mass per unit length of $8.0 \mathrm{t} / \mathrm{m}$ ) [16]. Repair works were made by incorporating additional elements. The existing elements were not removed nor weakened, while all connections were made using rivets or high strength bolts. Pier C was strengthened by additional piles and head beams, and by a new reinforced concrete layer around the existing pier.

\section{Load testing at the Sava Railway Bridge}

Detailed testing of the bridge was conducted after its reconstruction. According to the Croatian National Standard HRN U.M1.046 [2], load testing must be conducted after bridge reconstruction and before the bridge is opened to traffic. The purpose of load testing is to empirically quantify the load bearing capacity of the structure, i.e., to verify theoretical hypotheses on the behaviour of the structure. The load testing consists of static and dynamic testing.

The static and dynamic loading was performed using two 119.5 $\mathrm{m}$ long train compositions, each consisting of a locomotive and 8 freight wagons. The mass of the locomotives was 80.0 t ( 4 axles, 20.0 t per axle) and they were $15.5 \mathrm{~m}$ long. Wagons, 13.0 $\mathrm{m}$ in length, were loaded with gravel, and their average mass was $79.8 \mathrm{t}$ ( 4 axles, $19.95 \mathrm{t}$ per axle). The total mass per train composition was approximately 720 t, i.e. $1440 \mathrm{t}$ for both trains.

\subsection{Dynamic testing}

Six train passages over the bridge were recorded in the scope of dynamic testing. The details of these train passages are shown in Table 1.

The trains passed across the bridge at the same time (in parallel on two tracks), except at the second pass in which the excitation was caused by the train passage on the west-side track. It was difficult to achieve simultaneous passage of trains across the bridge at higher speeds. At the sixth passage, when the speed was $75 \mathrm{~km} / \mathrm{h}$, the train on the east-side track passed over the bridge with a delay of about 9 seconds compared to the train on the west-side track. This resulted in $187 \mathrm{~m}$ distance at the time of passage across the bridge, which can be seen in the measured displacement records shown in Section 5.

During dynamic testing of the bridge, displacements were measured by two RTS models with the sampling frequencies of $10 \mathrm{~Hz}$ and $20 \mathrm{~Hz}$. The RTS measuring point was placed at one quarter of the main span. Both RTS models were set on stable ground at a distance of $60 \mathrm{~m}$ from the measuring point (reflector). The reflector was fixed on the main girder at one quarter of the main span from the south-west side of the bridge (Figure 2).

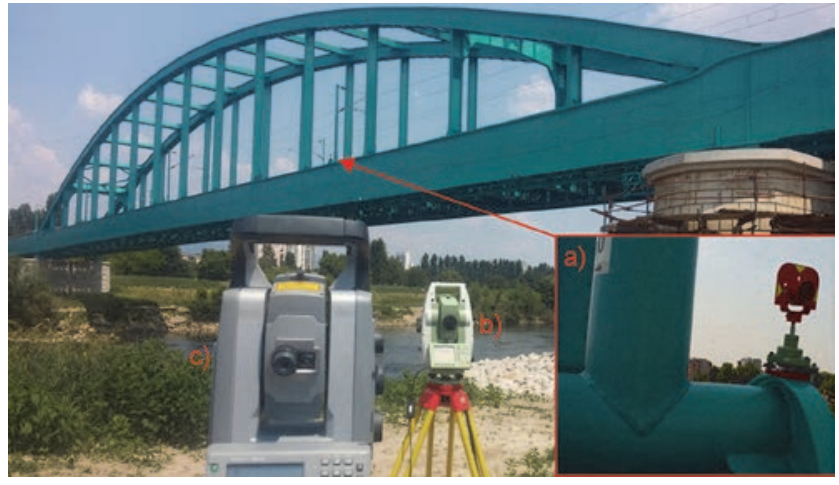

Figure 2. Position of RTS instruments and reflector; a - reflector; b - RTS 1; c - RTS 2 

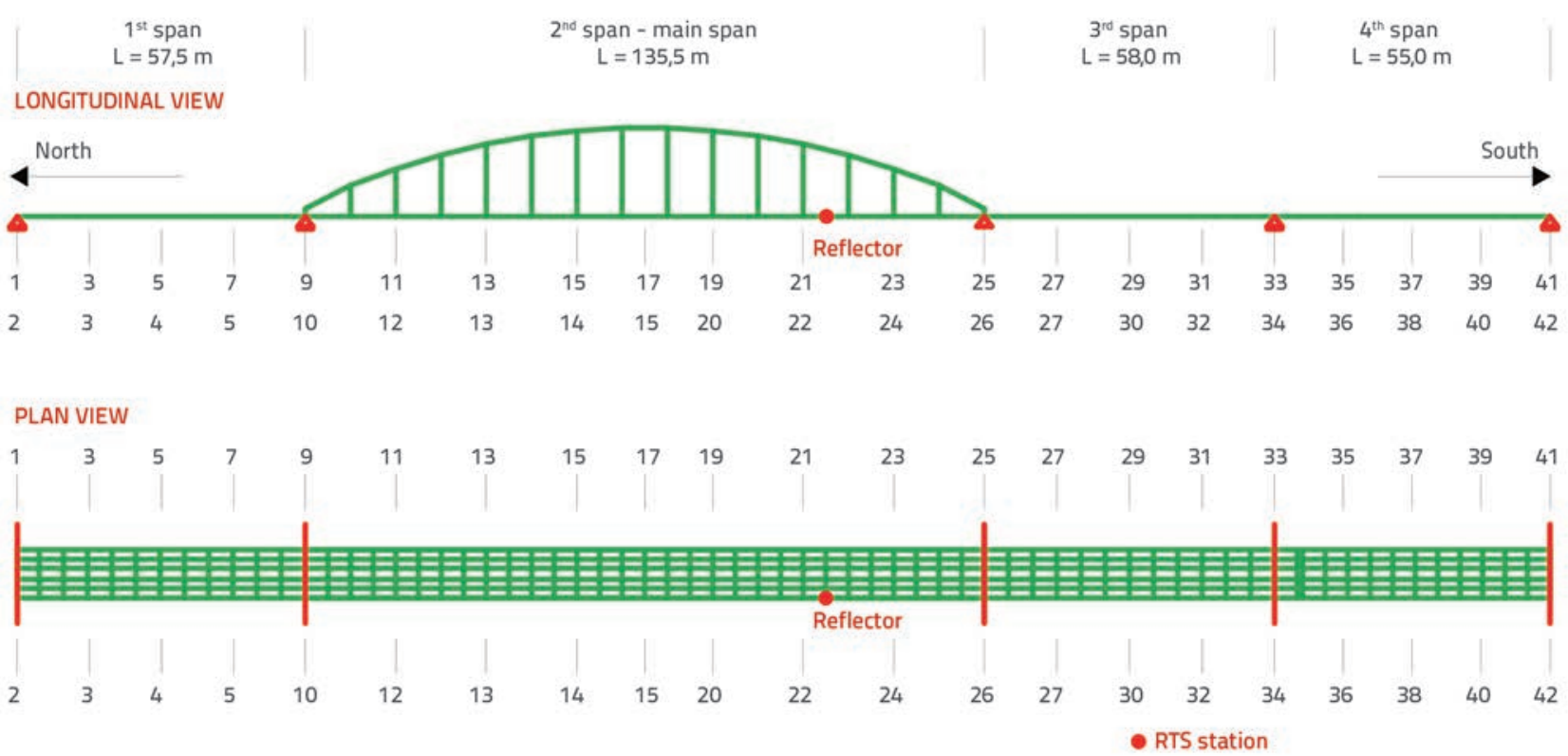

Figure 3. Accelerometer, RTS and measurement point (reflector) positions along the bridge in longitudinal layout (above) and plan view (below)

Modal parameters of the bridge were determined using the Operational Modal Analysis (OMA). During implementation of the OMA, accelerations were measured at 42 points during ambient excitation. Positions of acceleration measuring points (1-42), RTS and reflector are shown in Figure 3.

\section{Robotic total stations}

RTS devices belong to a new generation of surveying instruments that are capable of recording the change of $3 D$ coordinates of a moving target by an automated process with the sampling frequency of up to $20 \mathrm{~Hz}$ [11]. Based on measurements of horizontal and vertical angles and distance to the reflector, RTS determines 3D coordinates of the reflector in a rectangular coordinate system, relative to the known coordinates. The accuracy of reflector coordinates depends primarily on the uncertainty of horizontal and vertical angle measurements, and on the uncertainty of the distance to reflector measurements. Today's RTS have the ability to measure angles with the precision of 1 " and the length of $1 \mathrm{~mm}$, which allows determination of the reflector $3 \mathrm{D}$ position with an accuracy of $1 \mathrm{~mm}$.

The suitability of RTS for monitoring dynamic displacements of flexible, oscillating structures has been tested in the scope of several studies [5, 10,12, 13, 17-19]. The results of these studies show that RTS has an advantage over other geodetic instruments in the case of dynamic displacements measurements where high level of accuracy (at millimeter level) is required. Also, the results of these studies show that RTS can accurately measure oscillation amplitudes larger than 5 millimeters. However, the achievement of this level of precision by RTS is limited by numerous factors and depends on RTS characteristics, the type of reflector, and atmospheric conditions during the measurement. Furthermore, the RTS performance is also influenced by kinematics (speed and acceleration) of a moving reflector as well as by changes in the kinematics of the reflector $[13,20]$. All these factors might affect determination of coordinates, and so the beam can momentarily be interrupted, which in turn can impact the data sampling frequency.

Due to the mentioned factors that affect RTS performance in kinematic measurements, two RTS models were used in this research to measure coordinates of the same reflector. This enabled comparison of the dynamic movements of the bridge measured with RTS instruments. Two RTS models used in the research are Leica TPS1201 with the sampling frequency of up to $10 \mathrm{~Hz}$, and TRIMBLE S8 with the sampling frequency of up to $20 \mathrm{~Hz}$ (Figure 4).
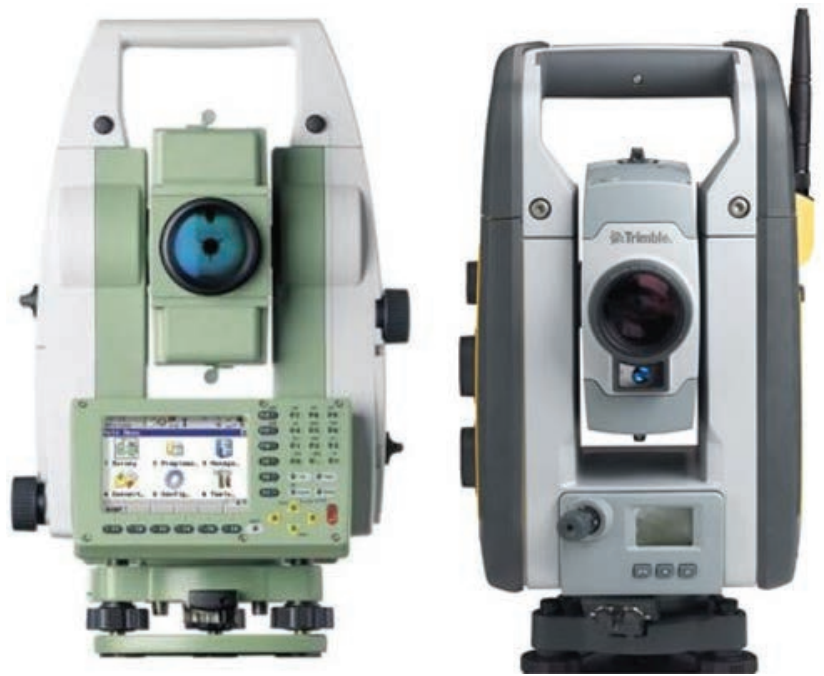

Figure 4. Leica TPS 1201 and Trimble S8

The Leica TPS 1201 sampling frequency set up to $10 \mathrm{~Hz}$ was not achieved and varied by about $7 \mathrm{~Hz}$ with irregular time intervals between individual records, which had already been established in previous studies. The Visual Basic (VB) application relying on 

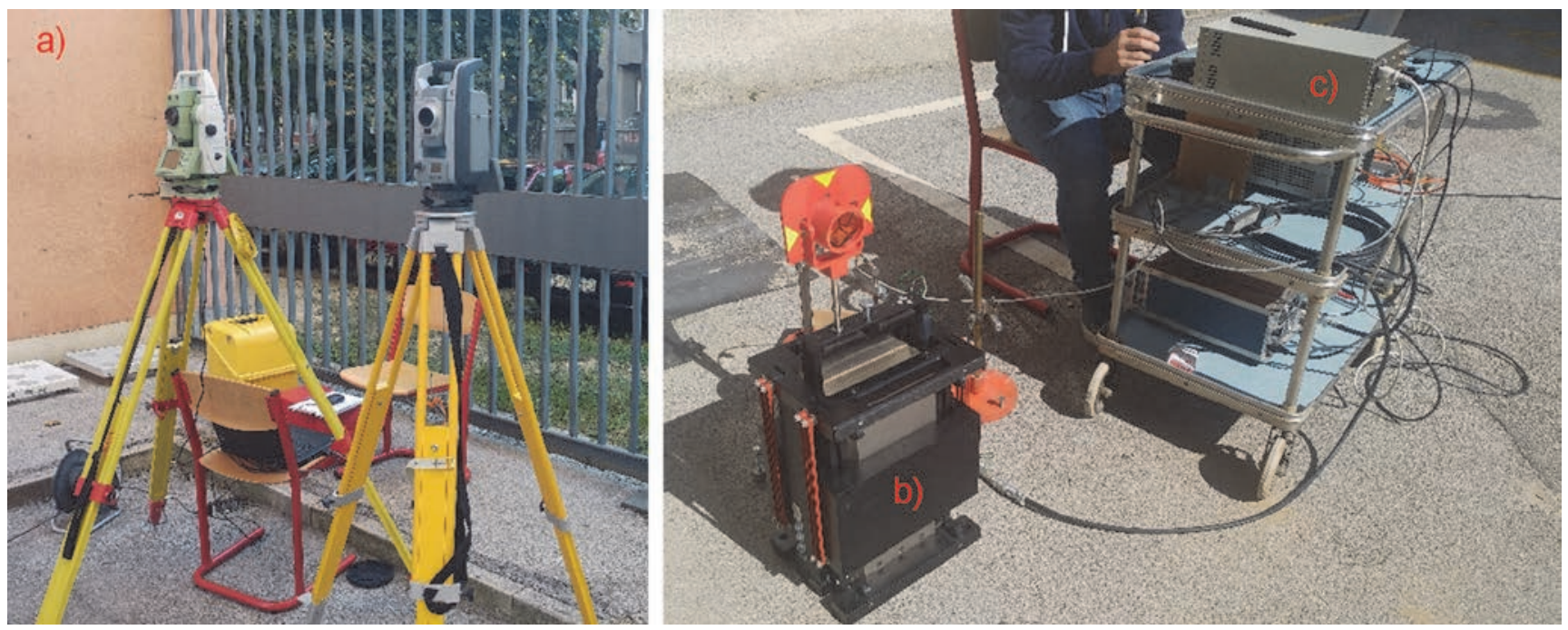

Figure 5. RTS instrument (a), electrodynamic shaker with reflector (b) and frequency generator with amplifier (c)

GEOCOM protocol was used in order to increase the number of recorded measurements [18]. The VB application controls the RTS measuring process via laptop and enables an increase in sampling frequency from $7 \mathrm{~Hz}$ to $10 \mathrm{~Hz}$. The robotic total station Trimble 58 was used in order to record 20 measurements per second. The process was also controlled by the laptop using the Trimble PC software.

\subsection{Testing of RTS in test field}

In previous studies related to RTS instruments [12,13,17-19], the possibilities of determining simulated displacements to the given amplitude of oscillation of less than $5 \mathrm{~mm}$ have not been sufficiently examined. For this reason, before determining displacement of the Sava Railway Bridge during load testing, RTS instruments were tested through measurement of artificially induced controlled displacements of less than 5 $\mathrm{mm}$. The testing was performed in a way that the robotic total stations were used for measuring position of the point that performs harmonic motion with predetermined amplitudes and frequencies of oscillation. The RTS testing was conducted in the courtyard in front of the Structural Testing Laboratory of the Faculty of Civil Engineering, University of Zagreb. Dynamic displacements were simulated using electrodynamic shaker with an amplifier and frequency generator (Figure 5).

The reflector was mounted on the moving arm of the electrodynamic shaker (Figure 5). The shaker was operated according to predefined frequency values and oscillation amplitudes. Simulated (predefined) oscillation amplitudes were controlled by the LVDT sensor HBM WA 50 that was previously calibrated to an accuracy class 1.

During the testing, the electrodynamic shaker was set to produce sinusoidal displacements with the amplitudes of $1 \mathrm{~mm}$, $2 \mathrm{~mm}$ and $4 \mathrm{~mm}$, and with the frequencies of $1 \mathrm{~Hz}, 3 \mathrm{~Hz}$ and 5 $\mathrm{Hz}$. The total of 9 tests were performed, and the testing of each amplitude and frequency of oscillation lasted for 30 seconds.
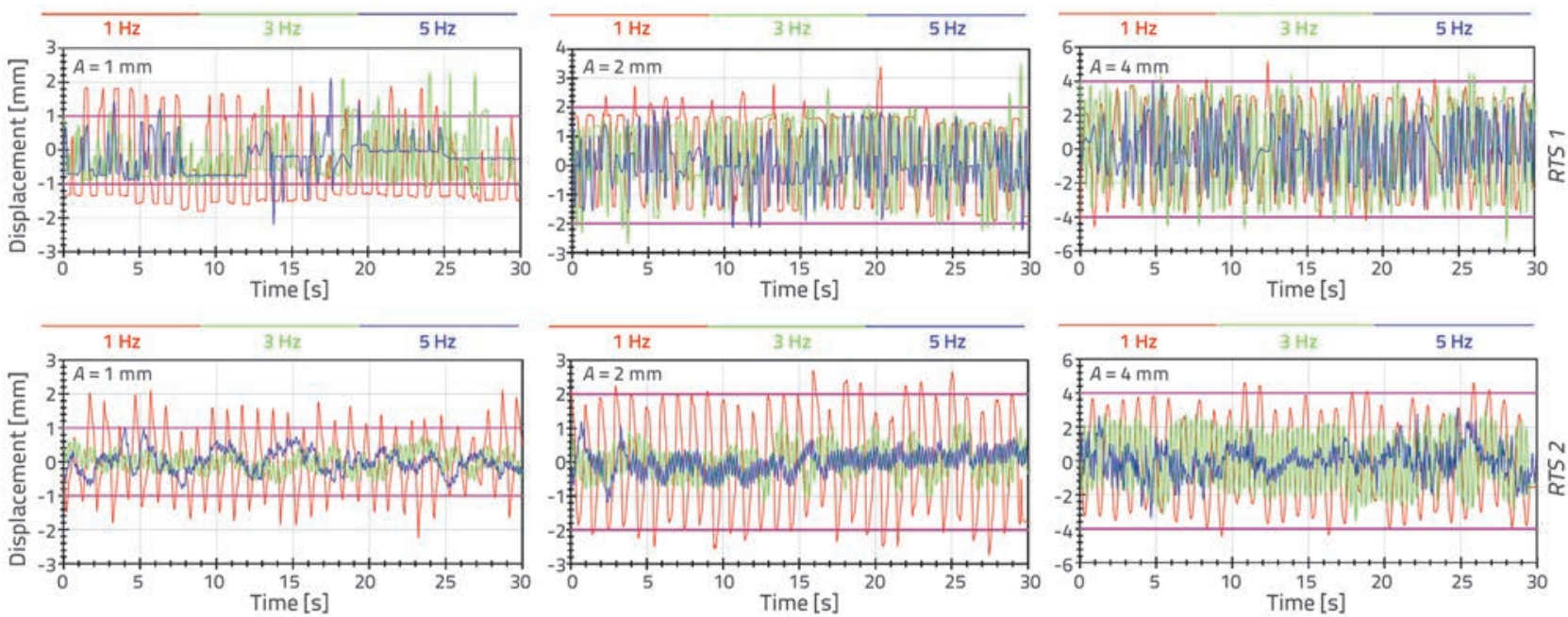

Figure 6. Displacements measured with RTS instruments in tests with predefined oscillation amplitudes of 1 mm, 2 mm and 4 mm 


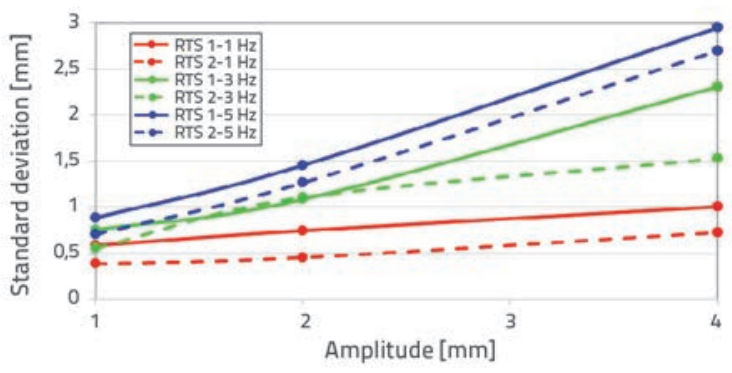

Figure 7. Standard deviation of differences in the tests performed

The distance between the RTS and electrodynamic shaker onto which the reflector was fixed was $60 \mathrm{~m}$, which corresponds to the measurement distance between the RTS and the reflector in the load testing of the Sava Railway Bridge. Measurement results for simulated dynamic displacements with predefined oscillation amplitudes of $1 \mathrm{~mm}, 2 \mathrm{~mm}$ and $4 \mathrm{~mm}$, are shown in Figure 6. Measurement results for different predefined oscillation frequencies are shown in different colours $(1 \mathrm{~Hz}$ - red, $3 \mathrm{~Hz}$ - green, and $5 \mathrm{~Hz}$ - blue). In the figures showing graphs of recorded displacements, RTS 1 denotes the Leica TPS 1201, while RTS 2 denotes the Trimble S8 instrument.

Measurement data quality indicators can be obtained simply by examining graphical presentation of measurement results, where it can be seen that the worst RTS measurement data were obtained when performing tests with the highest defined frequency $(5 \mathrm{~Hz})$ and the smallest amplitude $(1 \mathrm{~mm})$. These results were expected because the set (defined) amplitude of oscillation was on the verge of the RTS achievable precision. Also, graphs show poor assessment of the simulated sine function with an increasing frequency of oscillation and reflector speed. In the light of the above, it can be concluded that the quality of RTS measurement data is significantly affected by the frequency of oscillation or reflector speed. Thus, at higher speeds, the reflector positioning accuracy, with the impact of errors that occur at angle and distance measurements, is influenced by the errors synchronising the operation of individual RTS sensors, as well as by the effect of the RTS mechanism for monitoring the reflector on the measurement itself.

The next step was to analyse differences between the measured and simulated dynamic displacements. Since the accuracy of the system that is used to simulate dynamic displacements significantly exceeds the accuracy of the RTS instruments, the

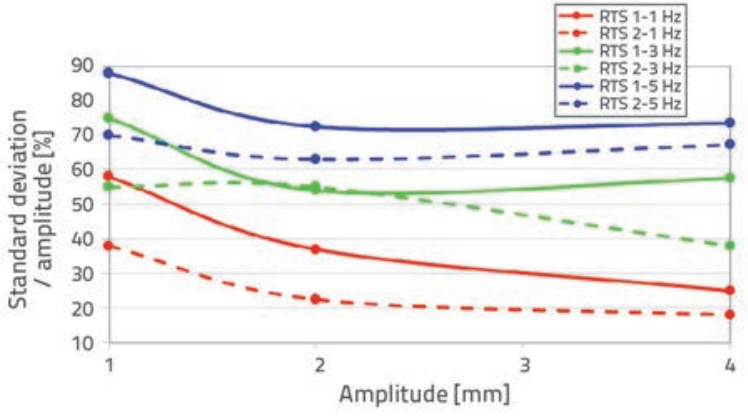

defined frequency and the oscillation amplitude can be taken as correct. The differences between the measured and the defined dynamic displacements were calculated for each 30-second test. Figure 7 shows standard deviations of differences in measured and predefined dynamic displacements, as well as the percentage of deviations with respect to the simulated amplitude.

Based on the calculated standard deviations of the tests performed, it can be seen that the most accurate results were obtained in tests with the lowest frequency of oscillation, while the larger standard deviation was obtained in tests with the frequency of $5 \mathrm{~Hz}$. Likewise, in tests with the given amplitude of oscillation of $1 \mathrm{~mm}$, the increase in standard deviation is up to $90 \%$ of the amplitude value (RTS 1). From the results shown, it is evident that the higher accuracy is achieved with the RTS 2 instrument, where standard deviation at the frequency of 1 $\mathrm{Hz}$ is around $20 \%$ of the measured amplitude (of $2 \mathrm{~mm}$ and 4 $\mathrm{mm})$. On the other hand, at $3 \mathrm{~Hz}$ standard deviation is about $40 \%$ of the measured amplitude even at the amplitude of $4 \mathrm{~mm}$. Therefore, the obtained results show that it is not possible to accurately determine the amplitude characteristics of dynamic displacements with the amplitude of 1 to $4 \mathrm{~mm}$ with the tested RTS instruments.

In addition to testing RTS instruments in the measurement of dynamic displacements, the subject of the examination was their ability to determine oscillation frequency of the sine signal with amplitudes of less than $5 \mathrm{~mm}$. Dominant frequencies of oscillation were determined in the tests using the Fast Fourier Transform (FFT) analysis.

Figure 8 shows the results of determined frequencies from data measured with RTS 1 in all tests $(1 \mathrm{~Hz}$ - red, $3 \mathrm{~Hz}$ - green, 5 $\mathrm{Hz}$ - blue).
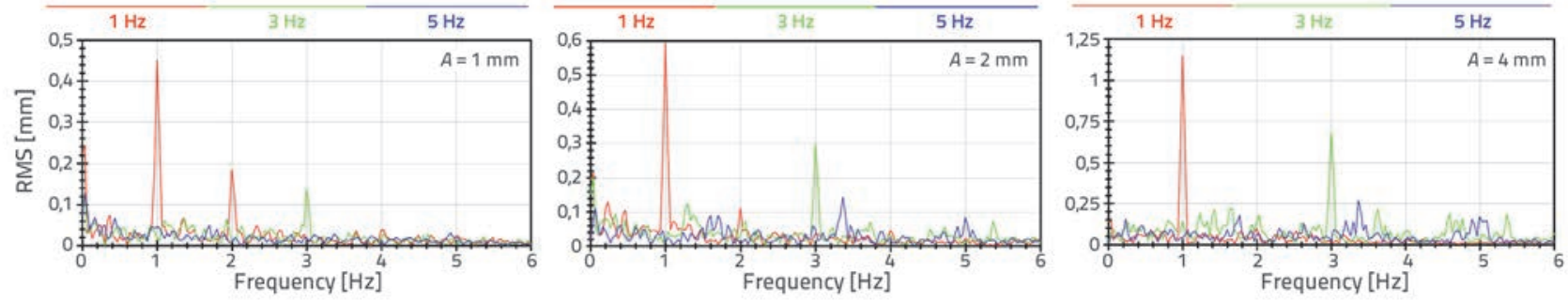

Figure 8. Spectral functions and frequencies determined by RTS 1 in tests with oscilation amplitude of $1 \mathrm{~mm}, 2 \mathrm{~mm}$ and $4 \mathrm{~mm}$ 

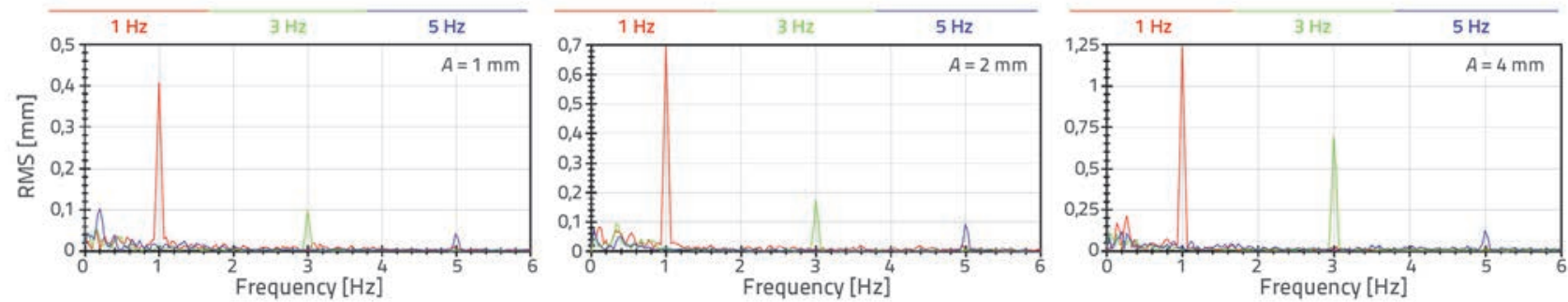

Figure 9. Spectral functions and frequencies determined by RTS 2 measurements in tests with oscilation amplitude of $1 \mathrm{~mm}, 2 \mathrm{~mm}$ and $4 \mathrm{~mm}$

As can be seen from the results, the frequency of $5 \mathrm{~Hz}$ could not be determined by RTS 1 in tests with any predetermined oscillation amplitude (Figure 8 - blue). The pre-set frequencies were determined in tests with the oscillation amplitude of $1 \mathrm{~mm}$ and the frequency of $1 \mathrm{~Hz}$ and $3 \mathrm{~Hz}$. In tests with the frequency of $1 \mathrm{~Hz}$, the resonant peak appeared at the frequency of $2 \mathrm{~Hz}$ as the first harmonic that is the after-effect of distortion of an ideal sine wave recorded by the instrument. In other tests, all pre-set frequencies were determined without significant noise. Figure 9 shows the results for frequencies determined from data measured with RTS 2 in all tests $(1 \mathrm{~Hz}$ - red, $3 \mathrm{~Hz}$ - green, $5 \mathrm{~Hz}$ - blue).

RTS 2 was able to determine frequencies in all tests, although low amplitude of the resonant peak was recorded in the test with the amplitude of $1 \mathrm{~mm}$ and the frequency of $5 \mathrm{~Hz}$. No filters were used in the analysis of data measured with the RTS instruments and in the determination of frequencies. With the application of digital filters prior to FFT analysis, noise can be reduced in spectral recordings, taking into account the fact that parts of the spectrum characterizing the studied dynamic phenomenon are not filtrated.

\section{Analysis of dynamic displacement measurement results}

The first data processing step was to transform determined coordinates of the moving target into a local Cartesian coordinate system with the origin in the centre of the reflector, and with one axis parallel to the direction of the bridge. This allowed analysis of reflector displacements along the longitudinal, lateral and vertical axes of the bridge. The next step of analysis was to identify the exact moment of the trains entering and exiting the bridge. These moments were identified in the field by the RTS instrument clock, as shown in Figure 10. They are determined separately for each train passing at different speeds.
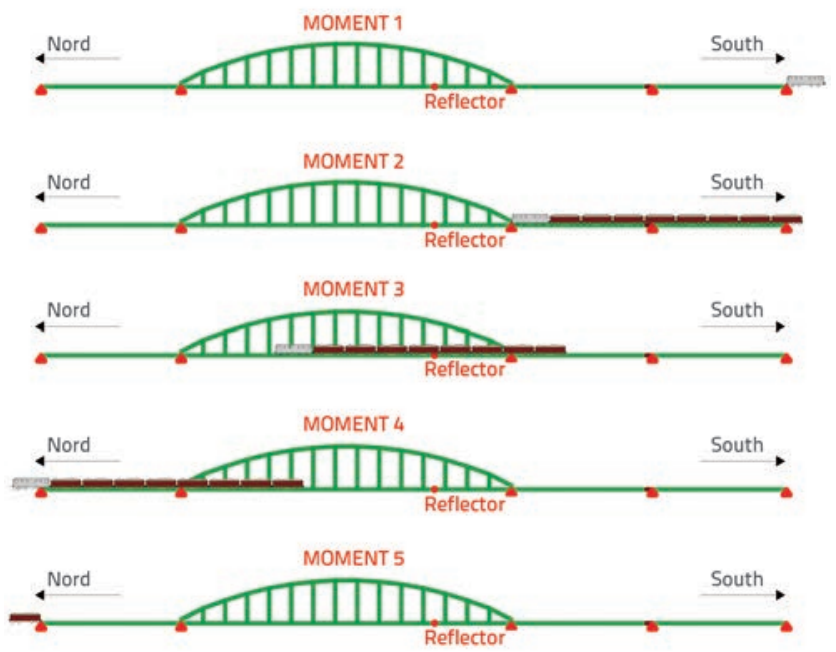

Figure 10. Position of trains at moments 1-5

The moments the trains enter and exit the bridge are defined by vertical lines numbered 1 and 5 in Figures 12-14 and 1619. The moments at which the maximum uplift of the RTS measuring point is detected in vertical direction are presented by vertical lines 2 and 4 (moments 2 and 4). The moment at which the maximum vertical deflection of the RTS measuring point was detected is presented by vertical line 3 (moment 3 ). The position of trains at these moments is shown in Figure 10, while vertical lines 1-5 are used in Figures 12-14 and 16-19 to denote the moments listed in the records of measurement of train passages at different speeds.

Measurement noise levels were estimated for both RTS instruments from the records of measurements carried out when the bridge was influenced solely by ambient load (Figure 11). To estimate the level of measurement noise, the reflector was placed above the pillar $\mathrm{C}$ in order to reduce to minimum the influence of ambient excitation.
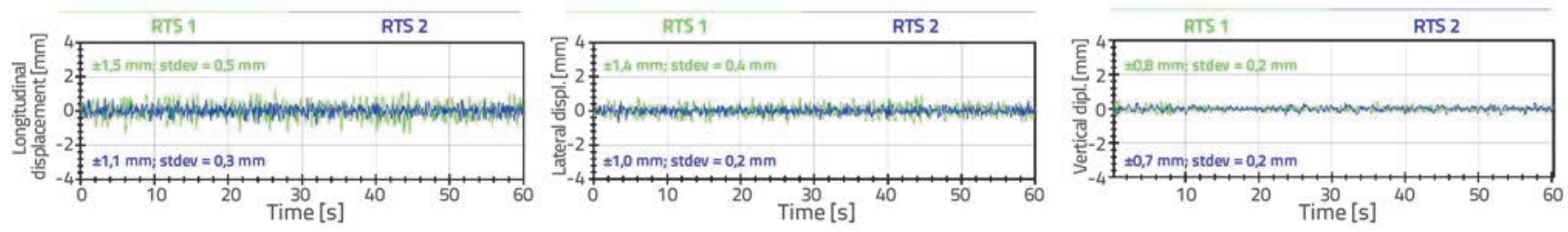

Figure 11. Dynamic displacements of the bridge when it was not subjected to excitation 
Vertical displacements determined by both RTS instruments over a period of 60 seconds, when the bridge was not influenced by excitation, were within the interval of $\pm 0.8 \mathrm{~mm}$, and the standard deviation of both RTS amounted to $0.2 \mathrm{~mm}$. Longitudinal displacements of the bridge determined by RTS 1 amounted to $\pm 1.5 \mathrm{~mm}$, whereas the lateral ones were \pm $1.4 \mathrm{~mm}$ (standard deviation $0.5 \mathrm{~mm}$ or $0.4 \mathrm{~mm}$ ). Longitudinal displacements determined by RTS 2 amounted to $\pm 1.1 \mathrm{~mm}$, and the lateral ones to $\pm 1.0 \mathrm{~mm}$ (standard deviation $0.3 \mathrm{~mm}$, or $0.2 \mathrm{~mm}$ ). These results show that the level of measurement noise is higher in the horizontal plane (longitudinal and lateral displacements) compared to the level of measurement noise in the vertical plane. Different levels of measurement noise in coordinate axes occur due to uncertainty in measuring the angle causing the corresponding uncertainty in determination of lateral position of the point (perpendicular to direction of RTS to the reflector), while the uncertainty of distance measurement causes uncertainty in determining longitudinal position of the point (in direction of RTS to the reflector). In accordance with the tests for the RTS instruments used (presented in Section 4), it is expected that the noise level during dynamic excitation will exceed the above described values.

\subsection{Vertical displacements}

Figure 12 shows vertical displacements of the bridge determined by RTS 1 in the quarter of the main span in passages 1-6 (Table 1). Bridge displacements measured during dynamic excitation consist of a long-period static component and a short-period dynamic component. Unfiltered measured displacements are shown in blue, the static component of vertical displacement is shown in red, and the dynamic component of displacement is shown in green. The static component was determined using a low-pass filter, which allows passage to all frequencies lower than $0.3 \mathrm{~Hz}$, while higher ones are attenuated. The dynamic component was determined by the use of a high-pass filter, which allows passage to all frequencies
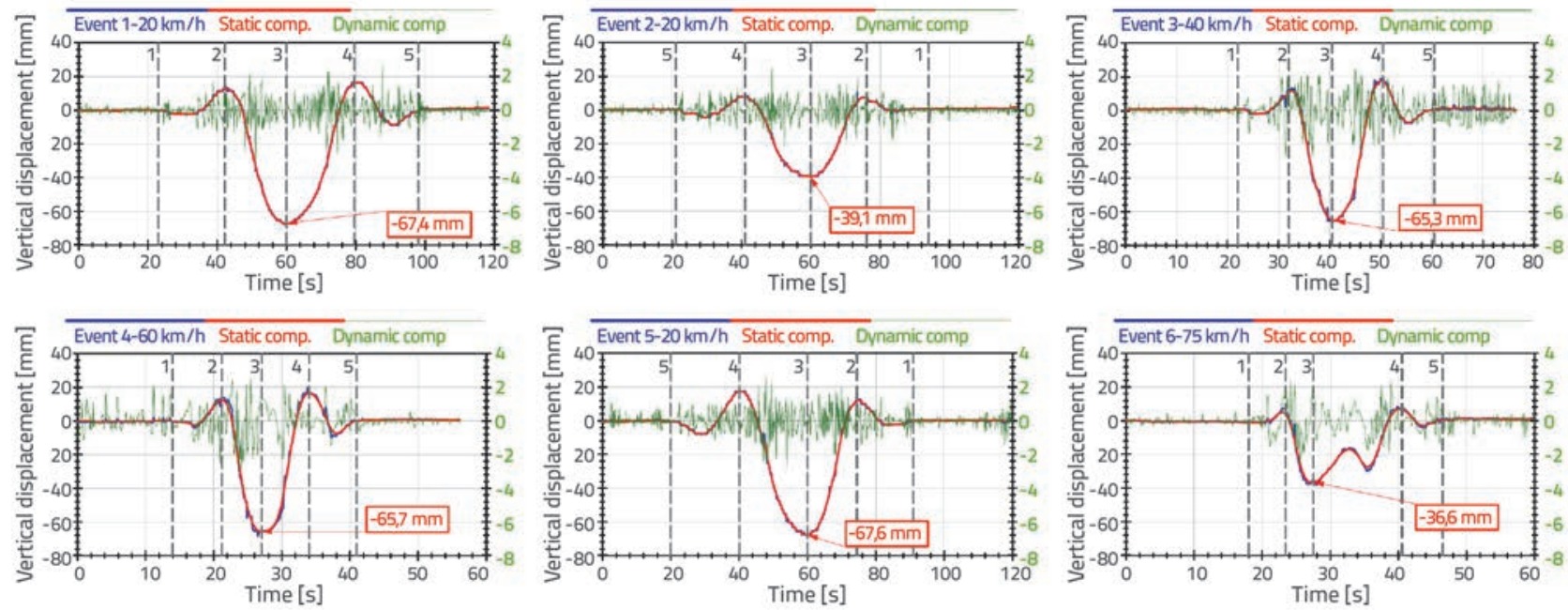

Figure 12. Vertical displacements of the bridge during passage of trains 1-6 measured by RTS 1
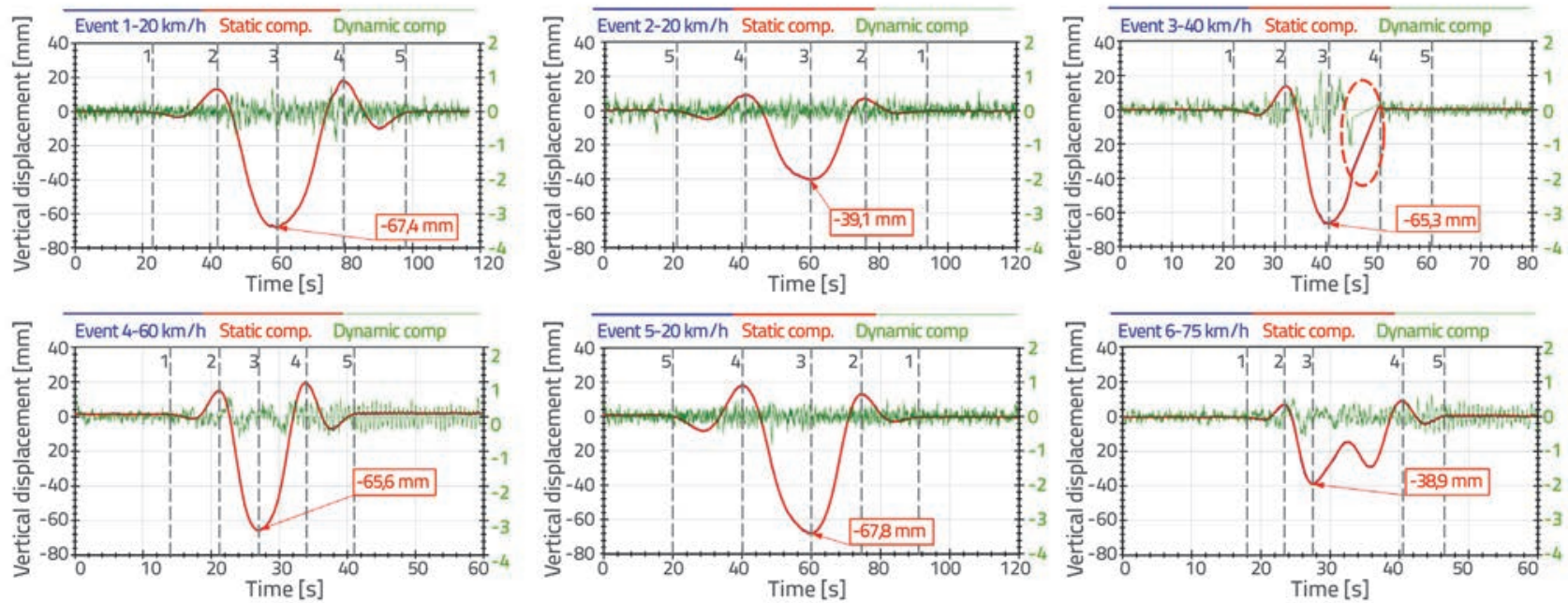

Figure 13. Vertical displacements of the bridge during passage of trains 1-6 measured by RTS 2 

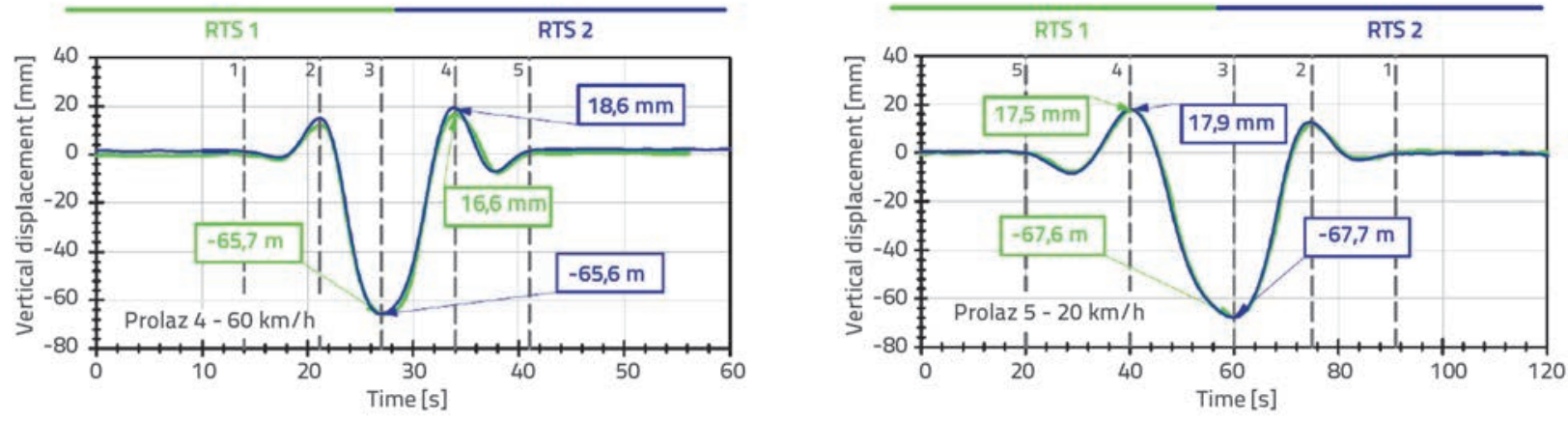

Figure 14. Comparison of static component of vertical displacement for train passages 4 and 5

higher than $0.3 \mathrm{~Hz}$, while lower ones are attenuated. The frequency of $0.3 \mathrm{~Hz}$ for the separation of static and dynamic components of displacement from the basic signal was selected as twice the frequency of train passage via the main span at the speed of 75 $\mathrm{km} / \mathrm{h}$, which was about $0.15 \mathrm{~Hz}$. Measured data were processed using the software package DIAdem 15.0. Vertical displacements of the bridge determined by RTS 2 in the quarter of the main span in passages 1-6 are shown in Figure 13 (Table 1).

Maximum static components of vertical displacement were determined at passage 5 . Static displacements obtained by RTS 1 and RTS 2 amounted to $67.6 \mathrm{~mm}$ and $67,8 \mathrm{~mm}$, respectively. Maximum static component of vertical displacement caused by the passage of one train (passage 2) was 39.1 for RTS 1 and $40.1 \mathrm{~mm}$ for RTS 2. The maximum elevation values measured by RTS 1 and RTS 2 amounted to $17.5 \mathrm{~mm}$ (passage 5) and $18.6 \mathrm{~mm}$ (passage 4), respectively. Lower displacement values determined at passage 6 were caused by the delay, i.e. by $187 \mathrm{~m}$ interval between the two trains passing over the bridge.

Only one unpredicted instance (i.e. error) occurred during the entire measurement process. This instance can be seen in Figure 13, marked in red circle for measurements performed by RTS 2 during event 3 . The cause of this unpredicted instance remains unknown and may perhaps be attributed to field conditions.

As can be noticed in Figures 12 and 13, both RTS instruments registered almost the same values of vertical displacement. Differences between static components of vertical displacement determined by the two RTS instruments amounted to $1 \mathrm{~mm}$, except at passage 4, where the difference in elevation was $2.0 \mathrm{~mm}$, and at passage 6 , where the difference of maximally measured displacement was $2.3 \mathrm{~mm}$. This indicates that the measurement precision achieved by the RTS instruments was satisfactory. The agreement between measured displacements can be seen in Figure
14 where static components of vertical displacement, determined by both RTS instruments at passages 4 and 5, are presented.

During the passage of trains, the main girder acceleration was measured in vertical direction in the middle of the central span. Dynamic displacements not exceeding $1 \mathrm{~mm}$ were determined by double integration of measured accelerations (Figure 15). The highest dynamic displacement value of $\pm 0.71 \mathrm{~mm}$ was determined at passage 3 at the speed of $40 \mathrm{~km} / \mathrm{h}$.

From the results gained from the dynamic components of displacements presented in Figures 12 and 13, it is evident that they are in the range of $\pm 2 \mathrm{~mm}$ for RTS 1 , while they are within the range of $\pm 1 \mathrm{~mm}$ for RTS 2 at all speeds. Since test results for measuring instruments (Section 4.1) show that it is not possible to accurately measure displacements at the levels of less than $1 \mathrm{~mm}$, it can be concluded that the displayed dynamic displacement components determined by RTS measurement are not reliable, and that they are primarily the consequence of noise and measurement errors.

\subsection{Horizontal displacements}

Unlike vertical displacements, the level of horizontal displacements of the bridge in the longitudinal and lateral directions was significantly smaller, because the load was primarily exerted in vertical direction during the passage of trains. Figure 16 and Figure 17 show bridge displacements determined by RTS 1 and RTS 2 in the quarter of the main span for the longitudinal direction at passages 1-6. Just like for vertical displacement, the measured displacement (blue) was divided into the static component (red) and dynamic component (green). In the time interval between moments 2 and 3, when trains passed across the main span of the bridge, the measured
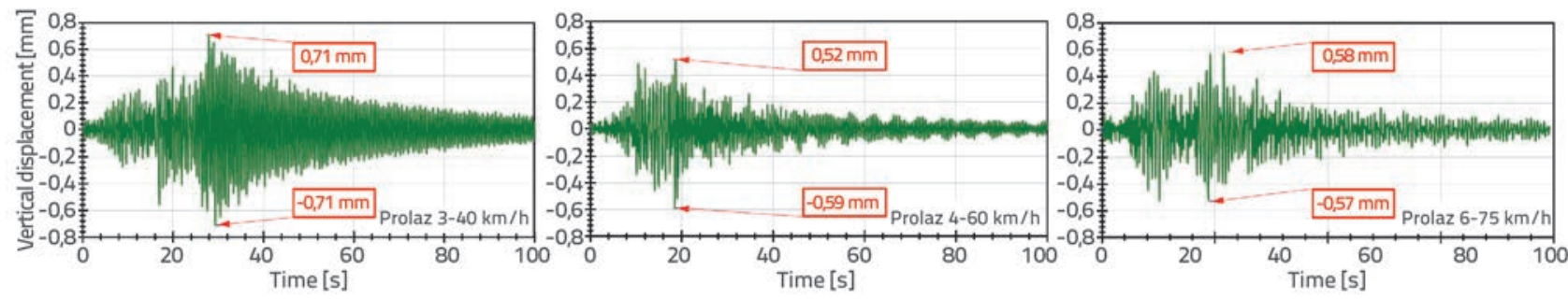

Figure 15. Dynamic displacements of main girder in middle span (integration of acceleration) 

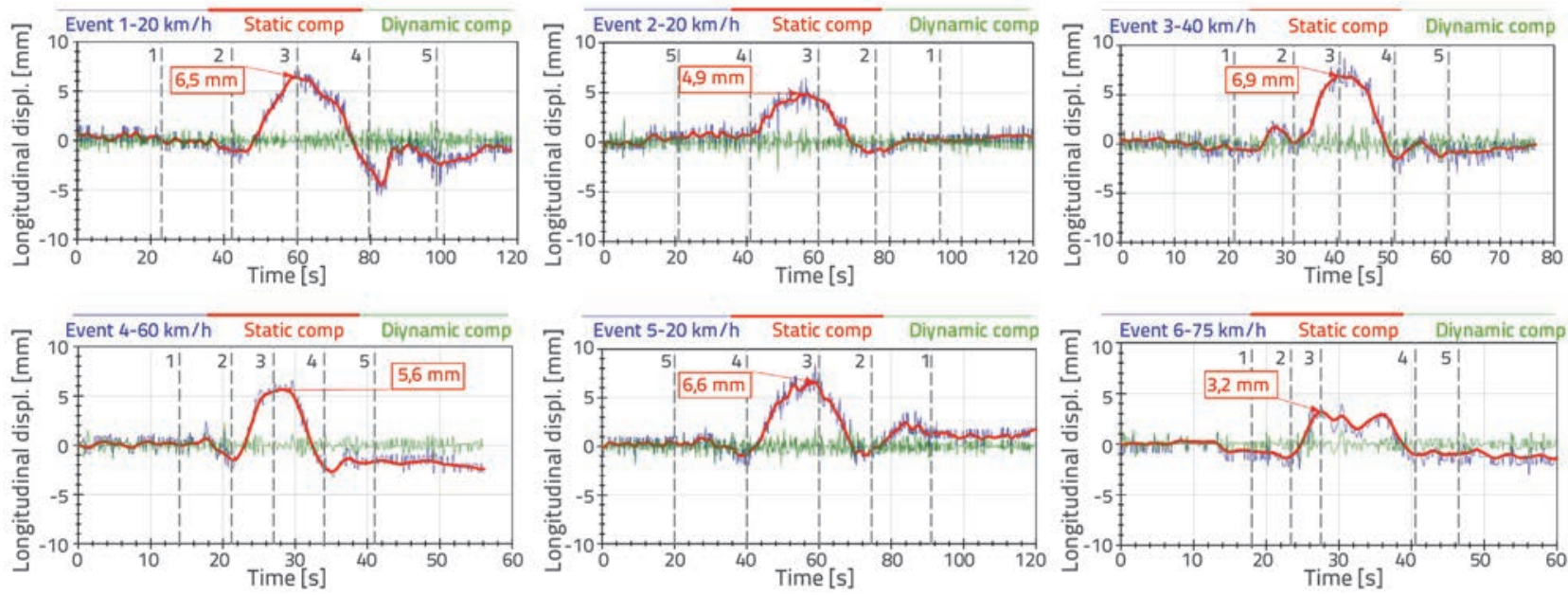

Figure 16 Longitudinal displacements of bridge in train passages 1-6 measured by RTS 1
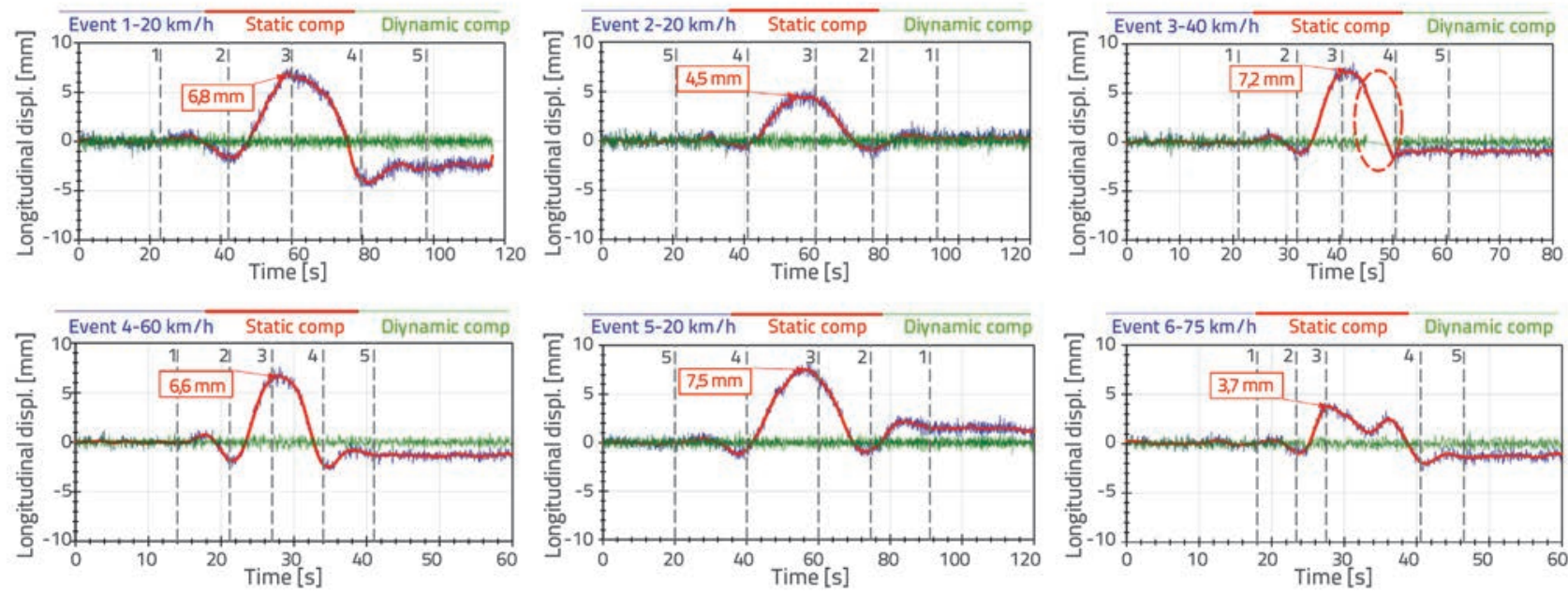

Figure 17. Longitudinal displacements of bridge in train passages 1-6 measured by RTS 2
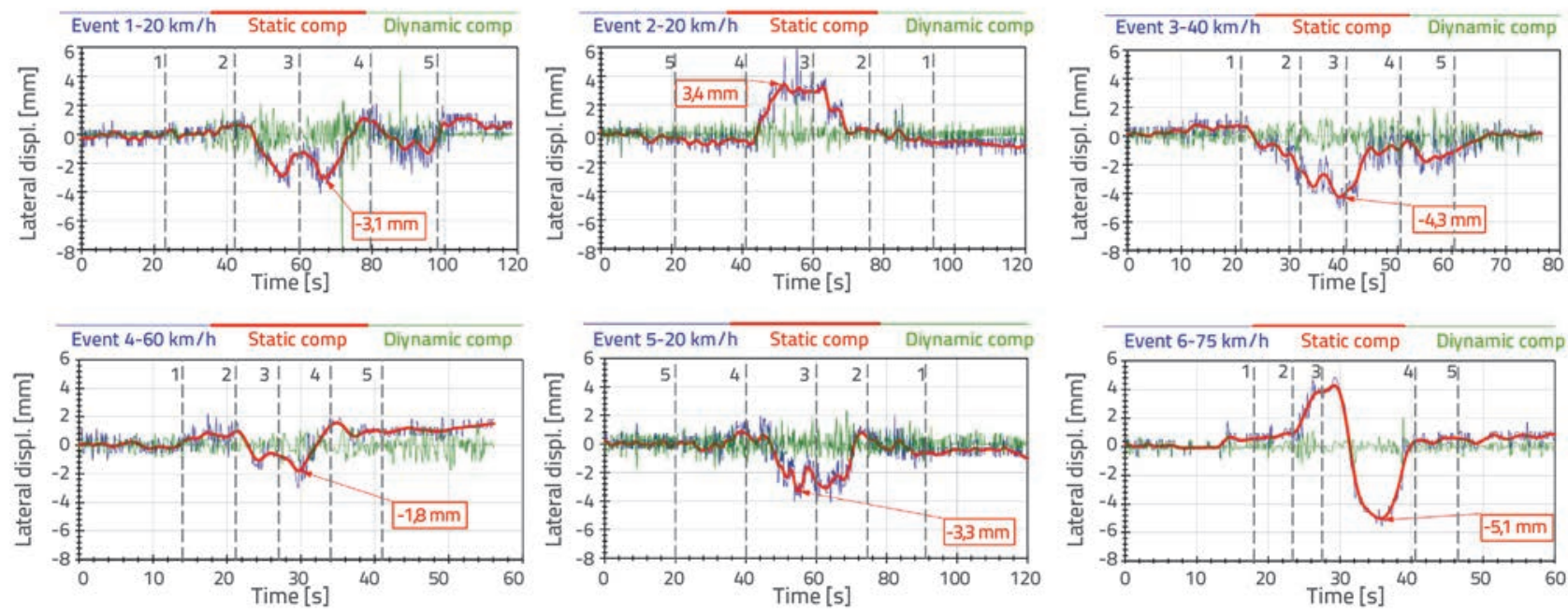

Figure 18. Lateral displacement of bridge at train passages 1-6 measured by RTS 1 

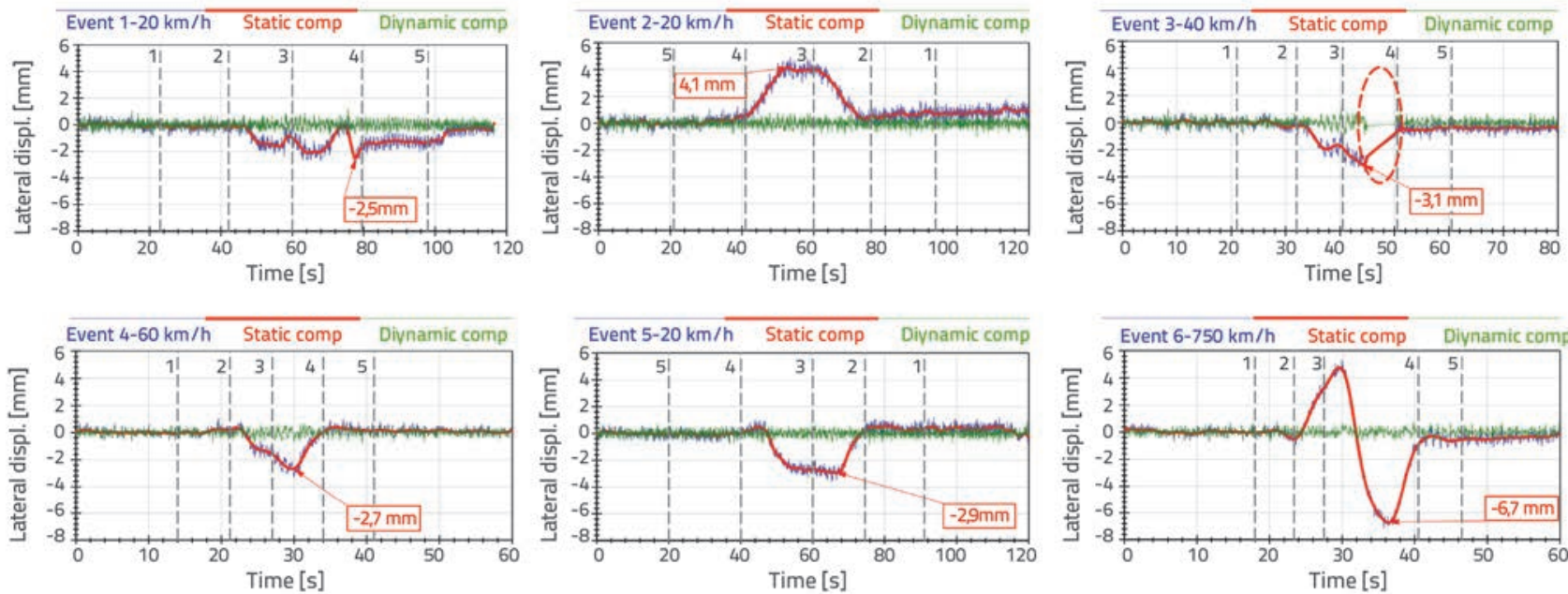

Figure 19. Lateral displacement of bridge at train passages 1-6 measured by RTS 2

displacements (Figure 16 and Figure 17 - blue colour) can clearly be distinguished from the noise measurements at all moments. Good agreement was observed for longitudinal displacements measured by both RTS instruments, where the static components of determined displacements differ by up to $1 \mathrm{~mm}$ (passages 4 and 5), despite of the fact that they are in the millimetre range. The maximum static component of longitudinal displacement determined at simultaneous passage of both trains was $7.5 \mathrm{~mm}$ for RTS 1 and $6.9 \mathrm{~mm}$ for RTS 2, while the same component at the passage of one train (passage 2) was $4.9 \mathrm{~mm}$ for RTS 1 , i.e. $4.5 \mathrm{~mm}$ for RTS 2. Given that all these displacements were determined in the time interval when the train passed over the main span of the bridge (time interval between the moments 2 and 3), it can be concluded with certainty that they show real response of the bridge caused by passing trains.

Figures 18 and 19 show lateral displacements of the bridge determined by RTS 1 and RTS 2. Lateral displacement values were smaller than longitudinal ones, but they were still higher than the estimated level of measurement noise. Maximum static component of lateral displacement was $6.7 \mathrm{~mm}$ for RTS 2, i.e. $5.1 \mathrm{~mm}$ for RTS 1 at passage 6 , while the displacements at passages 1-5 amounted to no more than $4.3 \mathrm{~mm}$. Higher level of lateral displacement at passage 6 was expected because

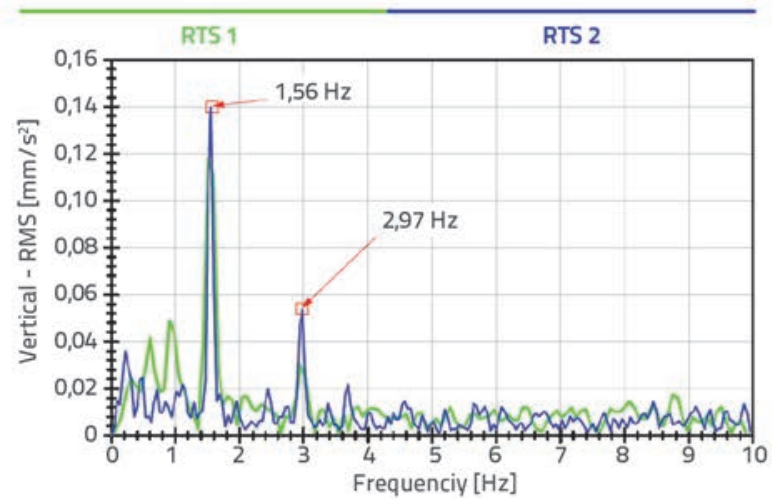

at this passage the train on the east-side track had a delay of about 9 seconds or $187 \mathrm{~m}$ as related to the train on the westside track, which caused bridge excitation in lateral direction. As with the displacement in vertical direction, dynamic components of displacements measured in longitudinal and lateral directions are in the range of $\pm 2 \mathrm{~mm}$ and $\pm 1 \mathrm{~mm}$ for RTS 1 and RTS 2, respectfully. It can be concluded that the displayed dynamic displacement components of horizontal displacement determined by RTS measurements are not reliable, and are primarily the consequence of noise and measurement error. As can be seen from the above results, both RTS instruments registered static components of displacement during passage of trains with the deviations within $\pm 1 \mathrm{~mm}$, with the exception of lateral displacement at passage 6 where the difference was $1.6 \mathrm{~mm}$.

\subsection{Identification of natural frequencies of the bridge}

The next stage of data processing involves computation of natural frequencies of the bridge from displacements measured by RTS. The FFT analysis was used to convert the time domain records of displacement measured by RTS to frequency domain. Natural frequencies were identified as resonance peaks of these spectral functions. Figure 20 shows the spectral function determined

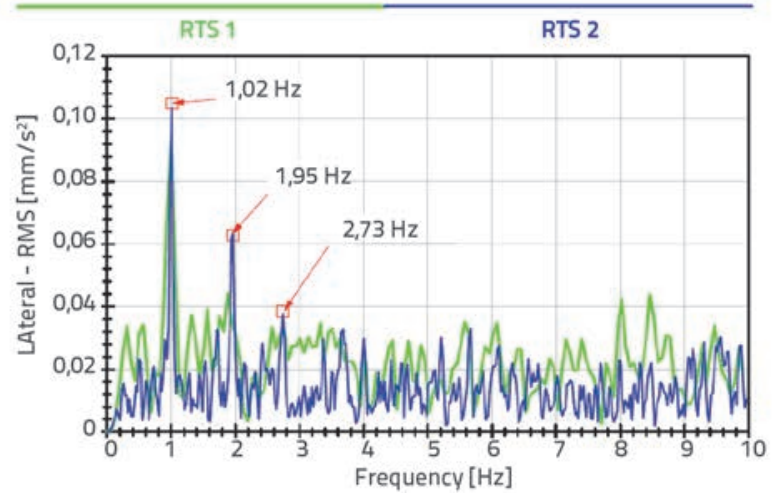

Figure 20. Spectral functions and natural frequencies identified from RTS measurements in vertical and lateral directions 
from vertical and lateral displacements measured by both RTS instruments. Presented spectral functions were obtained by averaging spectral records for all 6 train passages over the bridge. Natural frequencies at $1.56 \mathrm{~Hz}$ and 2.97 $\mathrm{Hz}$ were identified based on displacements measured in vertical direction, while frequencies at $1.02 \mathrm{~Hz}, 1.95 \mathrm{~Hz}$ and 2.73 $\mathrm{Hz}$ were identified from displacements measured in lateral direction. Spectral functions presented in Figure 20 reveal that RTS 2 gives clearer resonance peaks. Natural frequencies determined from RTS measurements were directly compared to those determined by OMA and to numerical natural frequencies determined from the FE model of the bridge. The spatial numerical model was developed using the software package SAP2000 v15.2.1. The material properties, geometry and dimensions of structural elements used in the FE model were taken from the main design of reconstruction of the bridge [23].

The OMA was conducted at ambient excitation, while natural frequencies, modal shapes and damping coefficients were determined by the methods of Frequency Domain Decomposition (FDD), using Brüel \& Kjaer's Software Package Pulse. The procedure is based on singular value decomposition (SVD) of power spectral density (PSD) matrix of measured responses [24]. The measurement was performed at 42 measuring points. At each point, accelerations were measured in vertical and lateral directions, giving a total of 84 measured degrees of freedom. Natural frequencies were determined based on 84 measured responses with standard deviations of 0.01 $\mathrm{Hz}$ to $0.06 \mathrm{~Hz}$. The conclusion derived from the above is that this technique gives reliable results.

Experimentally determined modal shapes (OMA) and numerical ones, together with the corresponding natural frequencies, are shown in Figure 21. The comparison of natural frequencies determined experimentally from RTS measurements, from OMA and numerical natural frequencies, is given in Table 2.

Table 2. Determined natural frequencies of the bridge

\begin{tabular}{|c|c|c|}
\hline $\begin{array}{c}\text { OMA } \\
\text { Nat. freq. } \pm \text { St. dev. }[\mathrm{Hz}]\end{array}$ & $\begin{array}{c}\text { RTS } \\
\text { Nat. freq. }[\mathrm{Hz}]\end{array}$ & $\begin{array}{c}\text { MKE } \\
\text { Nat. freq. }[\mathrm{Hz}]\end{array}$ \\
\hline $1.01 \pm 0.01$ & 1.02 & 1.03 \\
\hline $1.57 \pm 0.06$ & 1.56 & 1.63 \\
\hline $1.96 \pm 0.01$ & 1.95 & 1.54 \\
\hline $2.73 \pm 0.03$ & 2.73 & 2.81 \\
\hline $2.98 \pm 0.04$ & 2.97 & 3.11 \\
\hline
\end{tabular}

The above presented results show excellent agreement between natural frequencies determined experimentally by OMA, and those determined from RTS measurements. Results of numerical frequencies determined from the FE model show some discrepancies when compared to the ones determined experimentally. The accuracy of the FE model is influenced by input parameters such as material properties, geometry and boundary conditions that are often not comprehended with sufficient accuracy.

It can be concluded that RTS instruments with the sampling frequency of $10-20 \mathrm{~Hz}$ can successfully be used for determining natural frequencies at medium and large span bridges with natural frequencies of less than $5 \mathrm{~Hz}$. The precision of displacement measurements is not crucial for the determination of the natural frequencies, i.e. it is more important to have a satisfactory sampling rate of measurements.

\section{Conclusion}

The paper shows the testing procedure and possibilities for using RTS instruments in dynamic testing of the Sava Railway Bridge after its reconstruction. Two RTS models measured vibrations of the bridge caused by two trains passing at speeds ranging from 20 to $75 \mathrm{~km} / \mathrm{h}$. The main objective of this research was to evaluate the ability of RTS to measure displacements in the range of several millimetres during dynamic excitation, and to determine natural frequencies of the bridge based on displacement measurements. Vertical displacements of the bridge determined during train passages were up to $67.8 \mathrm{~mm}$, while horizontal (lateral and longitudinal) displacements were up to $7.5 \mathrm{~mm}$. 
Almost identical vertical displacement values were registered by both RTS instruments. Differences between the static components of vertical displacements determined by the two RTS instruments amounted to $1 \mathrm{~mm}$, except for the passage 6 where the difference of maximum measured displacements was $2.3 \mathrm{~mm}$. Differences between static components of horizontal displacements amounted to $1.6 \mathrm{~mm}$. Despite millimetre displacement range, an excellent agreement of horizontal displacements measured by both RTS can be noted. Considering that these displacements were identified at specific time of the trains passing through the main span of the bridge (the time interval between moments 2 and 3), it can be concluded with certainty that the measured horizontal displacements show real response of the bridge caused by passing trains.

The RTS instruments demonstrated the ability to identify static components of bridge displacement (horizontal displacements of the bridge) with satisfactory precision of a few millimetres only. At the same time, the dynamic components of displacements identified by RTS proved to be unreliable, and so it may be concluded that they are primarily the consequence of noise and measurement error.

Displacements measured by RTS were converted from time domain to frequency domain using the FFT analysis. First, five natural frequencies of the bridge were identified. Natural frequencies at $1.56 \mathrm{~Hz}$ and $2.97 \mathrm{~Hz}$ were identified from vertical displacements, and those at $1.02 \mathrm{~Hz}, 1.95 \mathrm{~Hz}$ and $2.73 \mathrm{~Hz}$ were identified from lateral displacements. Natural frequencies determined by
RTS measurements show excellent agreement with natural frequencies determined by ambient acceleration measurements at 42 measuring points in vertical and lateral directions.

Results obtained by testing RTS instruments show that it is not possible to accurately determine amplitude characteristics of displacements lower than $4 \mathrm{~mm}$. However, from the same measurements of simulated sinusoidal displacements with amplitudes of $1 \mathrm{~mm}, 2 \mathrm{~mm}$ and $4 \mathrm{~mm}$, it was possible to determine the frequency characteristics of up to $3 \mathrm{~Hz}$ with RTS 1, while RTS 2 registered frequencies of up to $5 \mathrm{~Hz}$.

The results presented in the paper show that, during dynamic excitation of bridges, RTS instruments can determine static components of displacement with sufficient accuracy in the range of a few millimetres, while natural frequencies of less than $3 \mathrm{~Hz}$ can be determined from dynamic components.

It can be concluded that RTS instruments are suitable for monitoring medium to large span bridges, and that their use is not restricted to monitoring only the constructions characterised by displacements higher than $10 \mathrm{~mm}$. It is important to point out that the limits of use of geodetic instruments for measuring dynamic displacements of structures is likely to expand in the near future thanks to growing precision and sampling frequency.

\section{Acknowledgments}

This work has been fully supported by Croatian Science Foundation in the scope of the project HRZZ-IP-11-2013-7714.

\section{REFERENCES}

[1] Paar, R.: Geoprostorne baze podataka objekata u sustavu gospodarenja autocestama Republike Hrvatske. Doktorski rad. Geodetski fakultet Sveučilišta u Zagrebu, Zagreb, 2010.

[2] HZN: HRN U.M1.046:1984, Ispitivanje mostova pokusnim opterećenjem.

[3] Kapović, Z., Herceg, Lj., Krolo, J.: Test loading of the Dubrovnik Bridge. Allgemeine Vermessungs-Nachrichten, (2005) 130, pp. 258-262.

[4] Kovačič, B., Kamnik, R.: Accuracy of trigonometric heighting and monitoring the vertical displacements. Engineering Modelling, 20 (2007), 1-4, pp. 77-84.

[5] Cosser, E., Roberts, G.W., Meng, X., Dodson, A. H.: Measuring the dynamic deformation of bridges using a total station. In Proceedings of the $11^{\text {th }}$ FIG Symposium on Deformation Measurements, Santorini, Greece, pp. 605-612, 2003.

[6] Roberts, G.W., Cosser, E., Meng, X., Dodson, A.H.: High frequency deflection monitoring of bridges by GPS, Journal of Global Positioning Systems, 3 (2004), pp. 226-231, https://doi. org/10.5081/jgps.3.1.226

[7] Li, X.: Integration of GPS, accelerometers and optical fibre sensors for structural deformation monitoring, In Proceedings of the $17^{\text {th }}$ International Technical Meeting of the Satellite Division of The Institute of Navigation. Long Beach, California, pp. 211-224, 2004.
[8] Ogaja, C., Li, X., Rizos, C.: Advances in structural monitoring with Global Positioning System technology: 1997-2006. Journal of Applied Geodesy, 1 (2007), pp. 171-179, https://doi.org/10.1515/ jag.2007.019

[9] Wieser, A., Brunner, F. K.: Analysis of bridge deformations using continuous GPS measurements. In Proceedings of $2^{\text {th }}$ International Conference of Engineering Surveying - INGEO 2002, Bratislava, Slovakia, 2002.

[10] Psimoulis, P., Stiros, S.: Measuring Deflections of a Short-Span Railway Bridge Using a Robotic Total Station. Journal of Bridge Engineering, 18 (2013), pp. 182-185, https://doi.org/10.1061/ (ASCE)BE.1943-5592.0000334

[11] Stempfhuber, W.: Verification of the Trimble universal total station (UTS) performance for kinematic applications. In Proceedings of Optical 3-D Measurement Techniques IX, Vienna, Austria, pp. 211-221, 2009

[12] Psimoulis, P., Stiros, S.: Measurement of deflections and of oscillation frequencies of engineering structures using robotic theodolites (RTS), Engineering Structures, 29 (2007), pp. 33123324, https://doi.org/10.1016/j.engstruct.2007.09.006

[13] Gikas, V., Daskalakis, S.: Full scale validation of tracking total stations using a long stroke electrodynamic shaker. In Proceedings of $23^{\text {th }}$ International FIG Congress, Munich, Germany, 2006. 
[14] Gikas, V., Daskalakis, S.: Comparative testing and analysis of RTS vs. GPS for structural monitoring using calibration measurements upon sinusoidal excitation. In Proceedings of $13^{\text {th }}$ FIG Symposium on Deformation Measurement and Analysis. Lisbon, Portugal, 2008.

[15] Palazzo, D.R., Friedmann, R.M.P., Nadal, C.A., Filho, M.L.S., Veiga, L.A.K., Faggion, P.L.: Dynamic monitoring of structures using a robotic total station, In Proceedings of $23^{\text {th }}$ International FIG Congress, Munich, Germany, 2006.

[16] Pravilnik o tehničkim uvjetima za sigurnost željezničkoga prometa kojima moraju udovoljavati željezničke pruge, Narodne novine 128/2008, Zagreb.

[17] Psimoulis, P., Stiros, S.: Monitoring of rigid structures using GPS and RTS - experimental and field evidence. In Proceedings of $4^{\text {th }}$ International Conference of Engineering Surveying - INGEO 2008, Bratislava, Slovakia, 2008.

[18] Marendić, A., Kapović, Z., Paar, R.: Mogućnosti geodetskih instrumenata u određivanju dinamičkih pomaka građevina. Geodetski list, 3 (2013), pp.175-190

[19] Lekidis. V., Tsakiri, M., Makra, K., Karakostas, C., Klimis, N., Sous, I.: Evaluation of dynamic response and local soil effects of the Evripos cable-stayed bridge using multi-sensor monitoring systems. Engineering Geology, 79 (2005), pp. 43-59, https://doi org/10.1016/j.enggeo.2004.10.015
[20] Zarikas, V., Gikas, V, Kitsos C.P.: Evaluation of the optimal design "cosinor model" for enhancing the potential of robotic theodolite kinematic observations. Measurements, 43 (2013), pp. 14161424.

[21] Stiros, S., Psimoulis, P., Kokkinou, E.: Errors introduced by fluctuations in the sampling rate of automatically recording uređajs: experimental and theoretical approach, Journal of Surveying Engineering, 134 (3), 2008, pp. 89-93, https://doi. org/10.1061/(ASCE)0733-9453(2008)134:3(89)

[22] Marendić, A.: Primjena geodetskih mjernih sustava u nadgledanju građevina s naglaskom na praćenje dinamičkih pomaka. Doktorski rad. Geodetski fakultet Sveučilišta u Zagrebu, Zagreb, 2011.

[23] Vranješ, B., Žderić, P.K., Vlahović, Z.: Glavni projekt rekonstrukcije i održavanja mosta Sava u Zagrebu, u km 427+754,06 pruge M202 Zagreb Gk - Rijeka, Građevinski projekt nosive čelične konstrukcije, br. 2336-Č/III, METAL - PROJEKT d.o.o., Zagreb, listopad 2010.

[24] Brincker ,R., Zhang L., Andersen, P.: Modal identification of outputonly systems using frequency domain decomposition. Smart Materials and structures, 10 (2001), pp. 441-445, https://doi. org/10.1088/0964-1726/10/3/303 